\title{
European experience of docetaxel and cisplatin in advanced gastric cancer
}

\author{
Arnaud D. Roth \\ Hopital Cantonal Universitaire, 1205 Geneve, Switzerland
}

\begin{abstract}
The combination of docetaxel with cisplatin in gastric cancer is a promising development. In a phase II study, $85-100 \mathrm{mg} / \mathrm{m}^{2}$ docetaxel plus $75 \mathrm{mg} / \mathrm{m}^{2}$ cisplatin was established as an active regimen in advanced gastric cancer (with an overall response rate of $56 \%$ ) with a manageable safety profile. Up to $300 \mathrm{mg} /$ $\mathbf{m}^{2}$ 5-fluorouracil (5-FU) given by continuous infusion for 2 of 3 weeks can be added to this regimen without an increase in appreciable toxicity. The efficacy of docetaxel-based regimens remains to be established by a randomized phase III study. However, the results of such trials are eagerly awaited, as are data from studies of docetaxel-based combinations in the adjuvant and neoadjuvant settings.
\end{abstract}

Key words Metastatic gastric cancer $\cdot$ Docetaxel

\section{Introduction}

In Europe, several avenues are being explored in the treatment of advanced gastric cancer. There is interest in the intensive use of chemotherapy (with weekly regimens supported by growth factors), in the use of 5fluorouracil (5-FU) as protracted continuous infusion or at high dose, and in oral fluoropyrimidines such as UFT, capecitabine, and S-1. However, the advent of newer drugs for this indication, notably docetaxel and irinotecan, has attracted considerable attention.

Preclinically, the combination of cisplatin and docetaxel has produced varying results, with either no therapeutic synergism observed in certain cell lines, or with additive or supra-additive effects observed in other cell lines [1-3]. Furthermore, the preclinical studies and

Offprint requests to: A.D. Roth

Arnaud D. Roth has received honoraria and medical research grants from Aventis Pharmaceuticals Inc.

Received: April 1, 2002 / Accepted: June 18, 2002 clinical studies in non-small cell lung cancer (NSCLC), in particular the phase III trials utilizing docetaxel in platinum-resistant or refractory disease, have suggested that there is a lack of cross-resistance between docetaxel and cisplatin [4-6]. This combination is also interesting, as the mechanism of action is different for the two agents and they have limited overlapping toxicities [7]. In phase I trials in various tumor types, the combination of docetaxel and cisplatin has been found to be active and feasible [8-15]. In a development program in gastric cancer, which began in 1996, docetaxel was combined initially with cisplatin in a phase II trial [16]. Following encouraging results, docetaxel was combined with both cisplatin and continuous 5-FU infusion in a phase I/II trial. This led to a three-arm randomized phase II study which compared docetaxel plus cisplatin against docetaxel plus cisplatin and 5-FU (TCF) and against epirubicin plus cisplatin plus 5-FU (ECF). Over the same period, a study of TCF in the neoadjuvant setting was initiated. This paper summarizes the results of these trials, which were conducted by the European Institute of Oncology and the Swiss group for Clinical Cancer Research (SAKK).

\section{Docetaxel plus cisplatin: a phase II study}

In the original phase II trial, the first 5 patients received $100 \mathrm{mg} / \mathrm{m}^{2}$ docetaxel over $1-2 \mathrm{~h}$ on day 1 , plus $75 \mathrm{mg} / \mathrm{m}^{2}$ cisplatin over $4 \mathrm{~h}$. However, this combination proved too toxic, and the following 43 patients were treated with $85 \mathrm{mg} / \mathrm{m}^{2}$ docetaxel and $75 \mathrm{mg} / \mathrm{m}^{2}$ cisplatin [16]. Treatment was administered every 3 weeks for up to eight cycles. Analysis was conducted on all 48 patients.

The mean age was 55 years (range, 27 to 75 years); $75 \%$ were men, $48 \%$ of performance status (PS) 0 and $52 \%$ of PS 1 . Appetite was good in $27 \%$, fair in $56 \%$, and poor in $15 \%$. The mean weight loss over the previ- 
Table 1. Efficacy results in the phase II trial of docetaxel plus cisplatin in the treatment of gastric cancer [16]

\begin{tabular}{lcc}
\hline Response $(n=48)$ & Number of patients & Percentage of patients \\
\hline Complete response & 2 & 4 \\
Partial response & 25 & 52 \\
Stable disease (for $\leq 3$ cycles) & 12 & 25 \\
Progressive disease & 6 & 13 \\
Early death & $2^{\mathrm{a}}$ & 4 \\
Non-measurable disease & 1 & 2 \\
\hline
\end{tabular}

${ }^{a}$ One early death, one suicide

Table 2. Hematological adverse events in the phase II trial of docetaxel plus cisplatin in the treatment of gastric cancer [16]

\begin{tabular}{lccccc}
\hline & $\begin{array}{c}\text { Percentage } \\
\text { of cycles } \\
(n=229)\end{array}$ & & \multicolumn{2}{c}{$\begin{array}{c}\text { Percentage } \\
\text { of patients } \\
(n=47)\end{array}$} \\
\cline { 2 - 3 } \cline { 5 - 6 } Toxicity grade & 3 & 4 & & 2 & 4 \\
\hline Leucopenia & $21 \%$ & $4 \%$ & & $40 \%$ & $11 \%$ \\
Granulocytopenia & $25 \%$ & $31 \%$ & & $24 \%$ & $57 \%$ \\
Thrombocytopenia & $0 \%$ & $1 \%$ & & $0 \%$ & $4 \%$ \\
Anemia & - & - & & $21 \%$ & $11 \%$ \\
\hline
\end{tabular}

Nine episodes of non-fatal febrile neutropenia occurred in eight patients

ous 3 months was $4.5 \mathrm{~kg}$. Of the patients included, $48 \%$ had had primary resection and $6 \%$ had adjuvant or neoadjuvant chemotherapy.

By intent-to-treat analysis, the overall response rate (RR) of $56 \%$ was very encouraging: two patients had a complete response (CR rate, $4 \%$ ) and 25 a partial response (PR, 52\%) (Table 1). The median time to progression (TTP) was 6.6 months and median overall survival (OS), 9 months. There was one early death and one case of suicide.

Toxicity was primarily hematological, with grade 4 leucopenia in $11 \%$, and grade 4 granulocytopenia in $57 \%$ of patients (Table 2). Nine episodes of febrile neutropenia occurred in eight patients, but none was fatal. No grade 4 non-hematological toxicity was seen, and the incidence of grade 3 toxicity was relatively low: $2 \%$ of patients experienced grade 3 fatigue, diarrhea, and mucositis; the incidence of grade 3 nausea/vomiting was $1 \%$, and that of neuropathy, fluid retention, and anaphylaxis was less than $1 \%$ for each (Table 3 ).

\section{Docetaxel plus cisplatin and 5-FU}

In considering a third agent with which docetaxel and cisplatin might be combined, attention focused on drugs with low hematotoxicity, such as 5-FU administered by continuous infusion. The choice of this third agent
Table 3. Non-hematological adverse events in the phase II trial of docetaxel plus cisplatin in the treatment of gastric cancer $(n=229$ cycles $)$ [16]

\begin{tabular}{lrrr}
\hline Toxicity grade & 1 & 2 & 3 \\
\hline Nausea/vomiting & $29 \%$ & $12 \%$ & $1 \%$ \\
Fatigue & $40 \%$ & $21 \%$ & $2 \%$ \\
Diarrhea & $5 \%$ & $5 \%$ & $2 \%$ \\
Mucositis & $13 \%$ & $4 \%$ & $2 \%$ \\
Neuropathy & $14 \%$ & $8 \%$ & $0.4 \%$ \\
Fluid retention & $9 \%$ & $4 \%$ & $0 \%$ \\
Anaphylactoid reaction & $2 \%$ & $0 \%$ & $0.4 \%$ \\
\hline
\end{tabular}

was also influenced by indications of activity: in the European reference regimen of ECF, both epirubicin and cisplatin are administered at relatively low doses $\left(50 \mathrm{mg} / \mathrm{m}^{2}\right.$ and $60 \mathrm{mg} / \mathrm{m}^{2}$, respectively), suggesting that much of the effectiveness of ECF is contributed by the continuous infusion of $200 \mathrm{mg} / \mathrm{m}^{2} 5$-FU.

The original intention in the phase I/II study of TCF was to have five dose levels, increasing the dose of cisplatin administered from $60 \mathrm{mg} / \mathrm{m}^{2}$ to $75 \mathrm{mg} / \mathrm{m}^{2}$, the dose of docetaxel from $70 \mathrm{mg} / \mathrm{m}^{2}$ to $85 \mathrm{mg} / \mathrm{m}^{2}$, and the dose of 5-FU (given as continuous infusion for 2 of 3 weeks) from $200 \mathrm{mg} / \mathrm{m}^{2}$ to $250 \mathrm{mg} / \mathrm{m}^{2}$. Because no doselimiting toxicties were experienced, the escalation of 5 -FU continued to a maximum of $350 \mathrm{mg} / \mathrm{m}^{2}$, accompanied by $75 \mathrm{mg} / \mathrm{m}^{2}$ cisplatin and $85 \mathrm{mg} / \mathrm{m}^{2}$ docetaxel.

The mean age of the 53 patients treated in the study was 57 years (range, 36 to 70 years); $69 \%$ were men, $50 \%$ of PS $0,44 \%$ of PS 1 , and $6 \%$ of PS 2 . The median weight loss over the previous 3 months was $2 \mathrm{~kg}$. Of the patients included, $52 \%$ had had primary resection, and $6 \%$ had adjuvant or neoadjuvant chemotherapy. Importantly, bidimensionally measurable disease was present in $81 \%$.

There were suggestions early in the escalation program of dose-limiting febrile neutropenia, diarrhea, nausea, and mucositis in certain patients. However, further experience showed that this response was not typical. Among the 52 patients treated, the overall rate of 
grade 4 leucopenia was $8 \%$ and that of grade 4 granulocytopenia, $54 \%$. The non-hematological grade 4 toxicities at $1 \%$ frequency, were nausea/vomiting, fatigue, mucositis, and diarrhea. These findings led to the recommendation of a combination regimen consisting of $85 \mathrm{mg} / \mathrm{m}^{2}$ docetaxel, $75 \mathrm{mg} / \mathrm{m}^{2}$ cisplatin, and $300 \mathrm{mg} / \mathrm{m}^{2}$ 5-FU.

Full report of this trial is presently in preparation.

\section{Discussion}

The data noted above are promising. However, randomized studies are needed to determine any improvement in outcome. To this end, the European Institute of Oncology and the SAKK have organized a randomized phase II study (which may develop into a phase III trial) in which patients with metastatic gastric cancer are randomized to TC, TCF, or ECF.

A relatively high incidence of febrile neutropenia at the start of the study led to a reduction in the docetaxel dose from $85 \mathrm{mg} / \mathrm{m}^{2}$ to $75 \mathrm{mg} / \mathrm{m}^{2}$, since when no adverse events have been reported.

The addition of docetaxel to chemotherapy is also being investigated in locally advanced resectable disease. In a randomized phase III study, patients with $\mathrm{T} 2 \mathrm{~N}+\mathrm{M} 0$ or T3-4 any N M0 cancer are being randomized to either: surgery followed (whenever possible) by four cycles of adjuvant TCF, or to four cycles of TCF before surgery. This study will demonstrate the feasibility and efficacy of a docetaxel-based approach to neoadjuvant and adjuvant treatment.

\section{References}

1. Wang H. Combined effects of docetaxel and cisplatin for nonsmall cell lines in vitro. Nagoya J Med Sci 2000;S63:129-37.

2. Aoe K, Kiura K, Ueoka H, Tabata M, Matsumura T, Chikarnori $\mathrm{M}$, et al. Effect of docetaxel with cisplatin or vinorelbine on lung cancer cell lines. Anticancer Res 1999;19:291-9.

3. Engblom P, Rantanen V, Kulmala J, et al. Additive and supraadditive cytotoxicity of cisplatin-taxane combinations in ovarian carcinoma cell lines. Br J Cancer 1999;79:286-92.
4. Ikubo S, Takigawa N, Ueka H, Kiura K, Tabata M, Shibayama T, et al. In vitro evaluation of antimicrotubule agents in human small-cell lung cancer cell lines. Anticancer Res 1999;19:3985-8.

5. Shepherd F, Dancey J, Ramlau R, Mattson K, Gralla R, O'Rourke $\mathrm{M}$, et al. A prospective randomized trial of docetaxel (Taxotere) versus best supportive care in patients with non-small cell lung cancer previously treated with platinum-based chemotherapy. J Clin Oncol 2000;18:2095-103.

6. Fossella FV, DeVore R, Kerr RN, Crawford J, Natale RR, Dunphy F, et al. Randomized phase III trial of docetaxel versus vinorelbine or ifosfamide in patients with advanced non-small cell lung cancer previously treated with platinum-containing chemotherapy regimens. J Clin Oncol 2000;18:2354-62.

7. Boisdron-Celle M, Gamelin E. Pharmacology of platinum analogs - taxanes interactions. Bull Cancer 2000;87:30-3.

8. Cole JT, Gralla RJ, Rittenberg CN, Marques CB, Robertson CN. Defining the dose of docetaxel (Taxotere) in combination chemotherapy of non-small cell lung cancer: preserving the efficacy with lower dose regimens (abstract 1671). Proc Am Soc Clin Oncol 1997;16:456a.

9. Le Chevalier T, Monnier A, Douillard JY, Ruffie P, Sun XS, Belli L, et al. Docetaxel (Taxotere) plus cisplatin: an active alternative and well tolerated combination in patients with advanced nonsmall cell lung cancer. Eur J Cancer 1998;34:2032-6.

10. Zalcberg J, Millward M, Bishop J, et al. Phase II study of docetaxel and cisplatin in advanced non-small cell lung cancer. J Clin Oncol 1998;16:1948-53.

11. Watanabe K, Hayashi I, Segawa Y, Hiraki S, Niitani H. Phase I/II study of docetaxel and cisplatin in patients with previously untreated metastatic non-small cell lung cancer (abstract 437P, Suppl 4). Ann Oncol 1998;9:91.

12. Schoffski P, Catimel G, Planting AS, et al. Docetaxel and cisplatin: an active regimen in patients with locally advanced, recurrent or metastatic squamous cell carcinoma of the head and neck. Results of a phase II study of the EORTC Early Clinical Studies Group. Ann Oncol 1999;10:119-22.

13. Caponigro F, Massa E, Manzione L, Rosati G, Biglietto M, De Lucia L, et al. Docetaxel and cisplatin in locally advanced or metastatic squamous-cell carcinoma of the head and neck: a phase II study of the Southern Italy Cooperative Oncology Group (SICOG). Ann Oncol 2001;12:199-202.

14. Vasey PA, Paul J, Birt A, Junor EJ, Reed NS, Symonds RP, Atkinson R, et al. Docetaxel and cisplatin in combination as firstline chemotherapy for advanced epithelial ovarian cancer. Scottish Gynaecological Cancer Trials Group. J Clin Oncol 1999;17:2069-80.

15. Gorbounova V, Khokhlova S, Orel N, et al. Docetaxel and cisplatin as first-line chemotherapy in patients with advanced ovarian cancer (abstract 1536). Proc Am Soc Clin Oncol 2000;19: 388a.

16. Roth AD, Maibach R, Martinelli G, Fazio N, Aapro MS, Pagani $\mathrm{O}$, et al. Docetaxel (Taxotere)-cisplatin (TC): an effective drug combination in gastric carcinoma. Swiss Group for Clinical Cancer Research (SAKK), and the European Institute of Oncology (EIO). Ann Oncol 2000;11:301-6. 